\title{
Biografias Necessárias: Vida e Lida de Adolescentes com Trajetória Infracional em Belo Horizonte
}

\author{
Cynthia Maria Santos Águido* \\ Rita de Cássia Fazzi* *
}

\section{RESUMO}

O artigo apresenta resultados preliminares de pesquisa realizada com adolescentes autores de ato infracional em cumprimento da medida socioeducativa de semiliberdade em Belo Horizonte. A partir da abordagem do curso de vida e de relatos biográficos, buscou-se compreender as sequências do ingresso e permanência de dois adolescentes em suas trajetórias infracionais, abordando a infância, interações sociais, adesão à prática infracional e aprofundamento do envolvimento no "mundo do crime". Apesar das especificidades e particularidades de cada trajetória e da forma única como os sujeitos constroem sua identidade ao longo de suas vivências e interações sociais, foi possível identificar semelhanças nas biografias narradas pelos adolescentes sujeitos da pesquisa.

Palavras-chaves: Adolescente autor de ato infracional; Relatos biográficos; Curso de vida.

* É graduada em Direito (UFMG) e em Serviço Social (PUC Minas), mestre e doutora em Ciências Sociais pela PUC Minas. Servidora pública do Estado de Minas Gerais desde 2008, com atuação na política de atendimento ao adolescente autor de ato infracional em cumprimento de medidas socioeducativas.

** É graduada em Ciências Sociais (UFJF), mestre em Sociologia (UFMG) e doutora em Sociologia pelo IUPERJ. Foi professora do Departamento de Ciências Sociais e do Programa de Pós-graduação em Ciências Sociais da PUC Minas até 2019. De 2003 a 2017 foi diretora do Instituto da Criança e do Adolescente (ICA), desenvolvendo pesquisa extensionista e capacitação voltadas para a temática dos direitos da infância, adolescência e da juventude, sendo vinculado à Pró-reitoria de Extensão da PUC Minas. 


\begin{abstract}
REQUESTED BIOGRAPHIES: LIFE AND WORK OF ADOLESCENTS WITH AN INFRACTION TRAJECTORY IN BELO HORIZONTE
\end{abstract}

This article presents preliminary results of a research carried out with adolescents in conflict with the law deprived of their liberty placed in a juvenile detention facility (semi-liberty socioeducational center for adolescents) in the city of Belo Horizonte. Based on the life course approach and biographical stories, it was sought to understand the circumstances of the involvement and permanence of two adolescents in their criminal trajectories, addressing childhood, socialization and integration, their engagement in criminal activities and deepening of the involvement in the "world of crime". Despite the specificities and particularities of each trajectory and the unique way in which the individuals construct their identity throughout their experiences and social interactions, it was possible to identify similarities in the biographies narrated by the adolescents involved in the research.

Keywords: Adolescent offender; Biographical stories; Life course.

Este trabalho apresenta resultados preliminares de pesquisa realizada com adolescentes autores de ato infracional em cumprimento da medida socioeducativa de semiliberdade em Belo Horizonte. A partir dos relatos biográficos dos adolescentes e da abordagem do curso de vida, buscou-se compreender as sequências do ingresso e a permanência dos adolescentes em suas trajetórias infracionais, abordando a infância, interações sociais na família e escola, adesão à prática infracional no início da adolescência e o aprofundamento do envolvimento até o acautelamento dos adolescentes. A pesquisa foi realizada entre os anos de 2017 e 2018 em duas unidades de semiliberdade, sendo uma delas destinada a adolescentes do sexo feminino e outra ao sexo masculino.

O adolescente que se encontra em uma Casa de semiliberdade passou por um processo judicial em que lhe foi atribuída a autoria de um ato infracional, sendo-lhe determinada uma medida socioeducativa. A semiliberdade implica em restrição da liberdade do adolescente, que permanecerá em uma casa, localizada em ambiente urbano e residencial, onde pernoitará, fará as refeições, receberá atendimentos da equipe técnica (psicóloga, assistente social, pedagoga, advogada) e poderá realizar atividades externas. Assim sendo, a escola, os cursos profissionalizantes, as atividades culturais e esportivas e os atendimentos de saúde são todos realizados nos equipamentos e serviços 
disponíveis na cidade. Além disso, é permitido ao adolescente passar finais de semana com sua família no seu domicílio.

Ao longo de toda a pesquisa, foram entrevistados 12 adolescentes do sexo masculino e seis adolescentes do sexo feminino, que tinham entre 16 e 18 anos de idade no momento da entrevista. Além disso, realizou-se análise dos prontuários institucionais desses 18 jovens. Neste trabalho, apresentaremos a trajetória de dois desses adolescentes.

A escolha por jovens em cumprimento de semiliberdade deve-se ao fato de se tratarem de indivíduos a quem se atribuiu a autoria de atos infracionais considerados graves ou por terem praticado infrações de maneira reiterada, tendo, pois, na maioria dos casos, um percurso infracional iniciado há mais tempo. Além disso, são adolescentes que continuam mantendo contato constante com o grupo familiar e a quebrada, não estando completamente privados de liberdade, mas sim em permanente relação tanto com a medida socioeducativa quanto com a cidade.

Importante destacar que a prática infracional certamente é realizada por adolescentes de todas as classes sociais, categorias de classificação racial e escolaridade, porém, os adolescentes mais captados e apreendidos pelo Sistema de Justiça Juvenil na capital mineira são, em sua maioria, do sexo masculino, têm entre 15 e 17 anos de idade, estão em situação de distorção idade-série, são estudantes de escolas públicas e declaram ser pretos ou pardos (MINAS GERAIS, 2018).

Antes das entrevistas, foram realizadas observações de atividades de rotina das Casas de semiliberdade, como oficinas pedagógicas e atividades de lazer. A partir da manifestação de interesse por parte dos adolescentes, as entrevistas foram agendadas. A proposta de ouvir os relatos biográficos dos adolescentes visava compreender as interpretações dos próprios indivíduos sobre suas experiências significativas na vida cotidiana e, para tanto, inspirou-nos a metodologia de narrativas biográficas aprimorada e utilizada por Rosenthal (2017).

Por meio da autoapresentação biográfica, o pesquisador pode acessar o processo de interiorização do mundo social vivenciado pelo sujeito ao longo da socialização, a integração das experiências biográficas no estoque de conhecimento e, por consequência, a constituição de esquemas de experiência que servem à orientação atual e futura do sujeito (ROSENTHAL, 2017, p. 19).

Importante destacar que o processo narrativo é atravessado pela intersubjetividade estabelecida na interação entre o sujeito biografado e o pes- 
quisador. Assim como outras pesquisas demonstraram (MALVASI, 2012; SANTOS, 2012; BUGNON; DUPREZ, 2010; FELTRAN, 2008; entre outras), é possível acessar as situações passadas e as experiências significativas por meio de entrevistas em que se estabeleça uma relação de confiança entre entrevistado e pesquisador. Contudo, é importante ter em mente que uma situação de pesquisa desencadeia um processo de seleção feito pelo entrevistado: ele não acionará todas as suas experiências passadas, mas apenas uma parte delas, enquanto outra parte será negligenciada.

$\mathrm{Na}$ entrevista narrativa, o entrevistado é convidado a falar sobre um determinado fato, tema ou período de sua vida e, na primeira fase da entrevista, ele não é interrompido pelo pesquisador, sendo apenas estimulado de forma não verbal, principalmente. Apenas na segunda fase da entrevista é que o pesquisador apresenta questões ao entrevistado. Santos (2012) destaca que, quando o pesquisador apresenta questões explícitas e direcionadas, ele "empresta” seu sistema de relevância ao entrevistado, o que contribui para que ele apenas reaja aos temas predefinidos.

Partindo dessa escolha metodológica, buscou-se compreender os percursos de vida dos garotos e das garotas que compartilharam suas histórias de vida e quais os sentidos atribuídos por eles às experiências que consideram significativas. No momento da entrevista, após serem informados de que o tema da pesquisa era a trajetória de adolescentes que se encontravam em cumprimento da medida de semiliberdade, foi solicitado aos adolescentes que contassem sua história de vida. Paralelamente às entrevistas, foram realizadas a leitura e análise do prontuário socioeducativo de cada um dos adolescentes, que consiste em uma pasta com documentos diversos, como fichas de admissão, registros de atendimentos técnicos com o adolescente e familiares, registros de comissões disciplinares, relatórios, cópias de sentenças judiciais, entre outros.

Ao longo da organização cronológica e das análises dos caminhos trilhados pelos adolescentes até sua adesão a práticas infracionais e permanência no "mundo do crime" ${ }^{1}$, utilizou-se da abordagem de Curso de Vida

1 Utilizamos o conceito de "mundo do crime" apresentado por Gabriel Feltran (2008): trata-se de um termo "nativo" das periferias onde o pesquisador realizou sua etnografia e designa "o conjunto de códigos sociais, sociabilidades, relações objetivas e discursivas que se estabelecem, prioritariamente no âmbito local, em torno dos negócios ilícitos do narcotráfico, dos roubos, assaltos e furtos.” (FELTRAN, 2008, p. 31) segundo a perspectiva dos adolescentes e jovens. O "mundo do crime" está contido no mundo social, que é mais amplo, abarcando a totalidade das relações sociais das periferias. 
de Michael Benson (2013), o qual ensina que o curso de vida de um indivíduo pode ser compreendido como o conjunto de trajetórias interligadas que ele vivencia. Trajetória é uma sequência de estados vinculados, que se encontram dentro de um domínio, como, por exemplo, a trajetória escolar, a trajetória profissional, a trajetória de maternidade ou de paternidade, a trajetória infracional, e outras mais. Por meio de transições, os indivíduos vão avançando sequencialmente pelos estados vinculados de cada trajetória.

A perspectiva do curso de vida se interessa por algumas dimensões da carreira criminal, como o início, o qual é marcado pela primeira vez que uma pessoa se envolve em um crime; a frequência; a gravidade das atuações; a duração da carreira e a desistência, ou seja, o ponto final de uma carreira criminosa (BENSON, 2013, p. 12) e agrega à tradição da carreira criminal um maior reconhecimento das conexões recíprocas entre trajetórias no crime e as trajetórias dos indivíduos em outros domínios de sua vida, como a trajetória familiar e escolar, o ingresso no mundo do trabalho, casamento, paternidade, entre outras. Assim, como ensina Benson (2013), as trajetórias no crime podem ser melhor compreendidas se forem analisadas dentro do contexto total da vida e do desenvolvimento do indivíduo.

$\mathrm{Na}$ análise do curso de vida de uma pessoa com trajetória infracional, é importante considerar a continuidade cumulativa, que se refere à maneira pela qual o comportamento em um momento da vida do indivíduo vai influenciar oportunidades e ações futuras. Assim, a continuidade cumulativa é um processo dinâmico em que o comportamento infrator em um ponto do tempo tem consequências que aumentam a probabilidade de o indivíduo continuar atuando em infrações em momentos posteriores, pois há um acúmulo de desvantagens, de experiências negativas que podem dificultar a saída ou desistência do crime (BENSON, 2013, p. 16). Essas desvantagens, como apreensões pela polícia, processos judiciais, encarceramento, processos de rotulação e estigmatização dos indivíduos como "infratores", têm um efeito de "bola de neve" e reduzem futuras oportunidades educacionais e de inclusão no mercado de trabalho legalizado (BENSON, 2013, p. 106). Mas, apesar desse efeito em cadeia do acúmulo de desvantagens, os processos sociais podem fazer com que mesmo indivíduos profundamente envolvidos com a criminalidade desistam do crime. Na pesquisa de Sampson e Laub, citada por Benson (2013), os autores defendem que essa mudança de rumos é possível e que a desistência pode ocorrer mais tarde, na fase adulta, por meio de processos que envolvem pontos de virada - fatos que 
desencadeiam mudanças e experiências significativas na vida do indivíduo, como o casamento, nascimento de um filho ou um emprego -, contestando a ideia de que as pessoas seguem trajetórias fixas e imutáveis.

A abordagem do curso de vida salienta a importância da primeira infância, pois há padrões de comportamento estabelecidos durante essa fase da vida que estão ligados a ações futuras dos indivíduos. Nesta perspectiva, a família tem importante papel sobre as trajetórias de vida dos indivíduos, sejam pais biológicos ou qualquer adulto que exerça o papel de cuidador. Além da provisão de necessidades básicas essenciais, a família começa a socializar e nutrir emocionalmente as crianças logo que nascem. Estudos apresentados por Benson (2013) sinalizam que famílias as quais exercem controle firme, mas caloroso das crianças, que são sensíveis às suas necessidades, que estabelecem com elas uma relação de autoridade, mas também de carinho e afeição, promovendo um senso de pertencimento e a construção de laços fortes estão ajudando a prevenir o envolvimento delas no crime (BENSON, 2013, p. 63-64). Contudo, há outras pesquisas que indicam que o comportamento dos filhos pode influenciar no comportamento ou na resposta dos pais.

É preciso, pois, tomar cuidado para não atribuir à família a "culpa” pela "produção" de infratores, como é comum, inclusive, entre profissionais que atuam em políticas públicas destinadas aos adolescentes no Brasil. Adolescentes infratores e não infratores podem ter famílias que têm um modo de funcionar muito parecido. Além disso, na mesma família, há irmãos infratores e não infratores. De todo modo, estudos sinalizam que crianças que crescem em lares conflituosos, ou sob menor supervisão de adultos, que têm mais liberdade para fazerem o que querem, com pouca ou nenhuma orientação dos pais ou cuidadores, tendem a se envolver em atos infracionais.

Com a chegada da adolescência, os adultos que exerceram o papel de cuidadores passam a ter menos influência sobre os adolescentes. Além de um importante reposicionamento no status social, eles vivenciam significativas mudanças biológicas e psicológicas que impactam as demais dimensões de sua vida. Estudos sobre a relação entre idade e envolvimento em crimes demonstram que os indivíduos se envolvem mais em práticas infracionais exatamente nesse período da vida: a idade de pico para o início da trajetória infracional é entre os 14 e 15 anos de idade e, aos 20 anos, a maioria dos infratores já desistiu ou começou a reduzir sua participação em atividades criminosas, como revelam pesquisas longitudinais sobre curso de vida de infratores (BENSON, 2013). 
Os adolescentes entrevistados nesta pesquisa se encontram entre seus 16 e 18 anos de idade, bastante jovens, portanto, e em cumprimento de medida socioeducativa de semiliberdade, não sendo possível, aqui, avaliar ou analisar com propriedade o fenômeno da desistência da prática infracional. Assim, a linha do tempo de cada adolescente entrevistado, que foi construída a partir das análises das narrativas e dos prontuários, expressa uma trajetória ainda em curso. Após a construção da linha do tempo, foram sistematizados trechos dos relatos e os sentidos atribuídos pelos adolescentes às experiências por eles vivenciadas. Foi possível perceber em todas as entrevistas que a trajetória infracional é uma entre várias trajetórias que o mesmo adolescente vivencia, como a trajetória familiar, a escolar, o trabalho, a religiosidade, as relações afetivo-sexuais, a maternidade, entre outras. Ninguém é infrator o tempo todo e a forma como compreendem seu percurso de vida não os coloca do lado oposto à "sociedade de bem", aos "humanos direitos".

Percebe-se que há um desconhecimento acerca desse adolescente a quem se atribui a autoria de atos infracionais, haja vista que as pesquisas enfatizam mais o "conflito com a lei" e menos o jovem, salvo exceções como os estudos de Feltran (2008), Malvasi (2012), Santos (2012) e Lyra (2013). Essa ausência do jovem como a ausência do objeto em si prevalece nos dados estatísticos, noticiários, relatórios e pesquisas técnicas que, muitas vezes, narram a história dos adolescentes à sua revelia. Mas é possível descobrir nesses jovens "algo mais que algozes sociais” (LYRA, 2013, p. 36), desconstruindo a ideia existente em tantos estudos de que as interações que esses adolescentes estabelecem com outros indivíduos são meras formas de instrumentalização do mundo da vida, como se fossem pessoas com uma única trajetória, o crime, e com a permanente disposição de praticar atos violentos.

\section{Os Percursos de Anderson e Ingrid}

“...creio que o mais difícil para mim era atestar a veracidade daquelas existências.” (LYRA, 2013, p.60)

"Minha mãe foi presa.” Essa foi a primeira frase de Anderson após lhe ter sido solicitado que contasse sua história de vida. Um fato que aconteceu quando ele tinha nove anos de idade. Foi essa sua escolha para iniciar a narrativa: 
Minha mãe foi presa. (Pausa) Aí, minha mãe foi presa e... ela ficou um... um pouco lá detida, lá, né? Ela ficou uma cara presa. Aí nisso, eu fui crescendo. É, pá. Fui vendo aí o crime como é que era, né? O tráfico como é que era, né? Aí eu empolguei, né? Vi que era dinheiro fácil, vida fácil e pá. Aí, depois eu comecei a fumar um baseado e pá. Isso, aí, vai, né? Isso aí... foi... Aí eu fui lá e comecei a envolver mais, enturmar mais. Aí, depois, acabou que eu comecei a vender droga, também. Comecei a envolver. Pá. Na hora que eu fui ver, eu já, já tava envolvido, já, né? Já tava meio que envolvido. Aí, nisso aí, minha mãe saiu da cadeia e viu que eu tava envolvido. Depois ela saiu, também, não estava envolvendo mais. Aí, agora ela tá de boa. E eu tô aí. Eu fui lá e rodei. Agora tô pagando medida, uê. (Anderson)

Desde o nascimento, Anderson morou com a avó e a mãe, mas mantinha contato com o pai. Contou que os pais chegaram a morar juntos, mas por pouco tempo. Também moravam com eles dois irmãos maternos, em uma favela de Belo Horizonte. Naquela quebrada, Anderson nasceu e cresceu, fez amigos, conheceu o crime.

Quando tinha nove anos de idade, sua mãe foi presa por tráfico e ele ficou sob os cuidados da avó. Contou que antes de ela ser presa, nunca imaginou que a mãe fosse envolvida com o crime. Visitava-a no presídio com uma tia materna. Sobre essas visitas, relatou:

Era chaina ${ }^{2}$, era cadeia mesmo. Nós chegava lá tinha que fazer os procedimento. Aí, eles [agentes prisionais] pegava a comida e virava a comida. Pá! Eu nem sabia o quê que tava acontecendo. Perguntava o quê que pega, mas... eu era mais sem noção no começo, mas depois, tipo, foi passando. Eu fui crescendo. Tipo questão de um ano mesmo. Eu, tipo, já sabia o que passava. O que era cadeia, já. Aí, eu com onze anos, onze pra doze, eu parei de visitar ela. Eu nem quis ir visitar ela por conta própria. (Anderson)

Após a prisão da mãe, Anderson começou a ficar mais tempo na rua e a sair com amigos. Aos 10 anos de idade, iniciou uso de maconha e, tempos depois, começou a usar loló. Aos 12 anos se envolveu com o tráfico:

2 Situação difícil, complicada, "embaçado". Contrário de tranquilo. 
Eu já tava, já tava muito enturmado. Ficava só no meio dos cara, né. Aí de repente, tipo, os cara tava tudo lá, né, Zé? Aí, de repente, chegou uns cara que era, tipo, uns cara de óculos ${ }^{3}$, mesmo, lá, tipo, os patrão já chegou e viu, tipo, via nós lá todo dia lá, né? Tinha um menino, que era parente... esse menino morreu, já. Mas é... quando eu fui entrar, eu andava muito com esse menino, aí. Aí, foi lá, esse patrão chegou e viu nós lá e, tipo, falou "não, eles vai ficar lá pra mim, não vai? Vai lá. Todo dia cês fica aqui. Vai lá. Vai lá.” O primo desse menino era gerente lá. Aí, tipo, eu andava com ele desde pequeno, assim, junto com a família dele. Eu ia na casa dele, lá, ele ia na minha. Aí, eu andava muito com ele. Nós ficava só com o primo dele lá. Aí, de repente, chegou outro patrão de outra firma e falou "não, cês vai ficar lá pra mim. Fica lá. Fica lá. Todo dia cês fica aqui. Cês é de menor, dá nada não. Nós acabou que nós foi. Nós falou "Vão, Zé? Vão!” Um falou com o outro "vão”. "Eu pago atividade pro cê, cê paga atividade pra mim”. Acabou que nós foi. Pegou a droga e começou a vender. (Anderson)

Você já sabia o que tinha que fazer?

Já, ué. Eu já tava, tipo, muito enturmado, já, né? Igual esse primo desse menino era gerente, ele mandava nós ir lá nos menino dele que vendia, buscar o dinheiro e pá. (Anderson)

Aos 14 anos, Anderson começou a trabalhar como servente de pedreiro, mas não abandonou a atividade no tráfico de drogas. Seu irmão mais velho também já estava envolvido no crime. O pai se mudou do bairro onde moravam e eles perderam o contato. Gostava de futebol e era bom de bola. Fez testes para jogar em times profissionais, mas a rotina de treinos entrou em conflito com o trabalho no tráfico. Abandonou os treinos, mas sempre jogava bola com os amigos de infância. Aos 15 anos, foi apreendido pela primeira vez, por porte de armas e roubo, mas foi absolvido, pois estava num carro roubado com amigos, porém, não havia participado do roubo. Na mesma idade, evadiu da escola, depois de conseguir conciliar a trajetória infracional com a trajetória escolar por quase três anos.

Eu estudava. Nunca tomei bomba não. Por isso que eu continuei estudando. Só que foi lá, chegou uma época que eu parei de estudar. No fi-

3 Chefe do tráfico, aquele que exerce a função também denominada como "patrão" do tráfico. 
nal do ano que eu tava no nono ano, eu parei de estudar. Ah, eu já tava muito envolvido, já, né? Chegou na época do Natal, eu tive que parar de ir pra escola. Eu estudava de manhã, tive que parar de ir pra escola pra vender droga, né? Pra ganhar dinheiro no Natal. Aí eu fui lá e parei de ir. Era época de prova e tudo, eu fui lá não passei. (Anderson)

Anderson iniciou a prática de roubos de carros aos 16 anos, mesma idade em que a mãe deixou o presídio. Foram cinco anos da vida de Anderson distantes da mãe e, por isso, ele considera que a avó assumiu a função materna em sua vida. Contou que a mãe ficou muito preocupada quando soube que ele estava envolvido com práticas infracionais e o orientava a deixar o crime.

Anderson iniciou trabalho como auxiliar de mecânico e continuou envolvido no tráfico e em roubos, mantendo uma trajetória infracional paralela à trajetória de trabalhos e "bicos" lícitos. Entre os 16 e os 17 anos, acumulou oito apreensões, sendo acusado de receptação, tráfico e roubos.

Começou a andar armado quando ia a bailes funk com os parceiros do tráfico. Depois, o uso de armas começou a ser mais frequente porque tinha guerras com grupos rivais.

Aos 17 anos, foi apreendido por roubo e porte de armas, sentenciado ao cumprimento da semiliberdade. Tatuagem do Tio Patinhas e a frase "Fique rico ou morra tentando". Retomou os estudos, fez cursos de profissionalização na área de marketing e empreendedorismo, mecânica de motos e informática. Nunca evadiu da Casa de semiliberdade. Contou que parou de vender drogas, mas continuou o uso de maconha. Disse que queria encontrar um emprego para não voltar para o tráfico, mas que gostava da época em que era envolvido. Cinco dos seus 17 anos de vida foram no movimento ${ }^{4}$.

Foi desligado após sete meses na semiliberdade. Devido a ameaças no território de moradia, alugou um barracão em uma cidade da região metropolitana de Belo Horizonte. Manteve o uso de drogas e vinha num esforço para não retomar as práticas infracionais. Devido a desavenças no novo local de moradia, mudou-se para outro bairro, em Belo Horizonte. Aos 18 anos de idade, em janeiro de 2019, Anderson foi assassinado devido aos conflitos decorrentes de seu envolvimento anterior com o tráfico de drogas.

4 Ser do movimento é estar envolvido com práticas infracionais, é "ser do crime”. Usos: "Quando eu tava no movimento." "Ele também é do movimento". 
Ingrid ria e sorria sempre. Divertiu-se com a entrevista e a possibilidade de narrar sua história. Ao iniciar, contou como era sua vida antes de conhecer o ex-namorado Robson:

Bom... ah eu... eu jogava futsal, estudava também. Fazia aula de dança. Só que eu tinha um grupo de dança.. aí eu fazia isso tudo. Era até... eu nem ficava... nem ficava em casa direito de tanto de coisa que eu fazia. Aí eu comecei a namorar com o cara aí que...nó... fez eu parar com tudo, com tudo. Com dança, com futsal, com escola. Ele queria que eu vivesse a vida só com ele, sem fazer nada. Tudo que eu tinha que fazer era fazer pra ele e perto dele, com ele, 24 horas, 48... grudado. Aí eu fui e abandonei, afastei de algumas amizade minha por causa dele. Que ele fazia... nossa... muita coisa. Ele xingava os outro, ameaçava os outro por causa de mim. Aí eu fui parei. Aí eu tentei largar dele várias vezes, não consegui. Aí um dia... eu tinha saído... fui comemorar o aniversário do meu irmão. Aí ele pegou e foi lá na minha casa, pegou minhas coisa tudo e levou pra casa dele e mandou mensagem pra mim. Aí eu fui... tava curtindo com meu irmão e depois quando eu cheguei em casa que eu fui ver as mensagens. Aí ele tinha pegado um tanto de coisa minha dentro da minha casa. Aí eu fiquei doida porque eu queria trocar de roupa, né, pra mim dormir e num tinha roupa porque ele tinha pegado tudo. Aí eu fui na casa dele. Aí quando cheguei na casa dele, ele tava... falou que queria conversar comigo. Aí eu já fui pegando minhas coisas. "Eu num quero conversa com cê não! Num sei nem pra quê que cê fez isso tudo aqui, tal...”. Aí ele foi trancou a porta. Aí já veio cá e como eu num queria conversar com ele, ele já veio agressivo pro meu lado. Aí ele me bateu. Começou a me bater, me deu duas facada. Aí eu fui, tomei a faca da mão dele e acertei ele. Pra mim, eu tinha acertado o braço dele. Só que eu acertei foi o coração dele. Só que aí eu fui... aí na mesma hora eu soltei a faca, né? E a faca caiu no chão... aí eu puxei... aí ele já começou a... a... ficar nervoso, né, porque ele tinha sido atingido com a faca. Aí eu fui... peguei e socorri ele. Chamei a família dele toda pra ajudar né? Só que eles achou que eu que tava ferida... porque eu tava ferida, né? Só que eles achou que eu que tava negoçando e me deixou né... fingiu que nem tava escutando eu chamar. Aí eu peguei socorri, chamei a polícia, chamei o bombeiro, chamei o SAMU... num tinha ambulância no momento. Aí na sorte encontrei um cara com carro e levei ele. Aí quando eu levei, levei ele, entreguei eu pra polícia. Aí quando chegou... chegou no hospital com vida. Depois de umas seis horas ele foi e morreu. Aí na hora que eu fui dar meu depoimento que chegou a notícia que ele tinha morrido, que ele não tinha aguentado. Aí eu tô aqui. (Ingrid) 
Ingrid sempre morou com a mãe e irmãos em uma cidade da Região do Vale do Rio Doce, em Minas Gerais. É a mais nova de quatro filhos, a única garota. Até seus quatro anos de idade, o pai também morava na mesma casa. Depois da separação, ele se mudou, mas continuaram mantendo contato frequente. Contou que, até os 13 anos de idade, estudava, praticava esportes e fazia aulas de dança. Um de seus irmãos era envolvido com o tráfico de drogas.

Aos 14 anos, mudanças significativas aconteceram em seu curso de vida: ela inicia o uso de maconha, envolvimento com o tráfico, abandona os estudos, o esporte e a dança:

Eu vi todo mundo ganhando dinheiro e falei "Nossa! Então é isso que eu quero".Todo mundo da minha rua. Todos os menino. Tinha até menina na época. Aí eu fui, cheguei no cara que era da minha rua, conversei com ele. Falei "Nó, véi, tal... tô precisando ganhar uma nota, tô vendo que cê tá ganhando dinheiro e tal..." Aí ele foi e me explicou "Não, eu vou te dar uma carga de... tipo de 150, 50 é seu e 100 é meu." Aí ele foi me deu essa primeira carga de 15, aí eu fui vendi 15, ele foi e já meu deu de 300. (...) Aí, olha a minha rotina era acordar cinco e meia da manhã, saía pra rua. Cinco e meia eu tomava banho, escovava dente, ia pra rua, já fumava um... fumava um chá e ficava lá. (...) Aí eu ficava na rua o dia inteiro, o dia inteiro eu ficava na rua. Aí minha mãe parou de me dar comida. Só deixava eu entrar pra tomar banho e mal-mal dormia... e deixava eu ir lá dormir. Parou de fazer comida pra mim. Parou de me dar as coisas por causa que eu tava fazendo isso. Aí eu ia pra rua. (...) Ninguém me via fazer nada, só via eu com dinheiro. Almoçava meio dia na rua. Comprava marmita pra mim. Quatro horas eu tomava café e... oito, nove horas da noite eu comprava um lanche pra mim. Aí eu entrava umas meia-noite pra dentro, que era o horário que acabava o meu turno, né? Entrava meia-noite. Escondida também. Eu esperava eles dormir, aí quando dava meia-noite eu entrava, dormia e acordava cinco e meia. E continuava a mesma coisa, todo dia, todo dia. (Ingrid)

Perguntei o que ela achava que tinha acontecido aos 14 anos para que sua vida mudasse tanto:

O meu pai. Falta do meu pai na minha vida. (...) Tipo assim... ah, eu envolvi mais porque... tipo... eu chegava na escola, as menina na sala tudo com trem novinho, chinelo novo, mochila nova e eu não podia 
ter porque era só minha mãe pra dar. Então, eu fui... daí eu revoltei com isso aí. Aí eu envolvi pra eu mesma comprar meus trem, num ficar pedindo minha mãe nada e nem meu pai. Porque a última vez que eu pedi ele dinheiro pra comprar o material pra mim, ele mandou é... eu falar pra minha mãe prostituir pra me dar. Aí eu tomei uma raiva danada dele. (Ingrid)

Ingrid começou a namorar um traficante, abandonou os estudos. Logo iniciou consumo abusivo de cocaína junto ao namorado. Chegou a praticar tentativa de homicídio com disparos de arma de fogo contra uma garota que teria disseminado inverdades sobre ela, mas nunca foi apreendida ou identificada como autora deste ato.

Aos 15 anos, estava vendendo tudo o que tinha adquirido com o tráfico (moto, anéis, cordões banhados a ouro) para consumir cocaína. Além disso, fumava quatro maços de cigarro de tabaco por dia. Contou que, certa vez, olhou-se no espelho e viu que estava muito diferente, "magra demais" e disse: "Vou abandonar isso." Na mesma época, vários amigos que eram envolvidos com o tráfico foram presos, incluindo o gerente local, colocando fim ao movimento. Ingrid deixou o tráfico. Sua mãe a matriculou novamente na escola e a adolescente voltou a fazer aulas de dança. Continuou o uso de maconha.

Pouco tempo depois, Ingrid conheceu Robson por meio de uma amiga. Seu ex-namorado traficante estava preso, o que facilitou a aproximação entre ela e Robson, que logo iniciaram namoro. Ele tinha 33 anos, ex-traficante, já havia sido preso, trabalhava com pintura de veículos. Era um homem ciumento e exigiu que a adolescente abandonasse os estudos e a dança. A relação do casal foi se tornando cada vez mais abusiva e violenta.

Aos 16 anos, Ingrid passou a morar com Robson, foi quando descobriu que ele havia voltado a vender drogas. Os dois iniciam um ciclo de brigas e desentendimentos, marcado por forte ciúme de ambos. Meses depois, Ingrid deixou a casa do namorado e terminou o relacionamento. Ela voltou a sair com amigas e conheceu Fernando, que é patrão no tráfico:

Aí eu fui na casa dele [Fernando]. Tava tendo festa. Aí minha amiga me chamou, eu fui lá e conheci ele. Só que no primeiro dia que eu fui, eu só conheci ele. Só que... (risos)... uma coisa que eu num posso fazer é beber cerveja, porque se eu beber cerveja eu fico acorajada, eu tomo 
coragem pra fazer as coisa que eu não faço. Aí eu tomei cerveja. Aí ele tava me olhando. Aí, sabe quando cê fica naquela agonia que os outro fica te olhando toda hora? Aí eu falei com a minha amiga "Nó, esse cara tá me olhando demais". Aí ela "Ele é o patrão daqui. Ele tá de olho no cê porque ele gostou do cê.” Aí eu falei... eu endoidei. (...) Aí eu falei: "Então eu quero ele, uê! Tô solteira mesmo". Aí eu fui pegar uma cerveja, ele foi e pediu pra ficar comigo. (Ingrid)

No dia seguinte, Fernando foi preso em casa, na companhia de outros traficantes e de Ingrid, mas ela foi liberada pela polícia. Ao saber desse ocorrido, Robson perseguiu e ameaçou Ingrid na rua e pelo telefone. Ela também o ameaçou por meio de mensagens de aplicativo de celular. Robson invadiu a casa de Ingrid quando não havia ninguém e levou as roupas e outros pertences dela para sua casa. Quando a adolescente foi até lá para buscar suas coisas, os dois brigaram de forma violenta, trocaram ameaças e agressões, o que culminou com a morte de Robson por uma facada desferida por Ingrid, conforme ela relatou no início de sua narrativa.

Como não há unidade socioeducativa feminina na cidade de Ingrid, ela foi transferida para Belo Horizonte. Entendendo que houve elementos de legítima defesa no caso, foi-lhe determinado o cumprimento de semiliberdade e não de internação, medida que comumente é aplicada em casos de homicídio. Ocorre que Ingrid não tinha registros de apreensões anteriores. Apesar de anos de envolvimento com o tráfico de drogas, ela nunca fora apreendida por isso. Foi considerada uma jovem sem antecedentes infracionais.

Mas... as coisa eu sempre fazia na calada, os povos só... só ouviu falar, mas ninguém nunca viu, tipo “Ah, a Ingrid fez isso...”. Nem os policial. Os policial era doido pra pôr a mão ne mim, prender eu. Eles ficava bolado porque toda vez que me pegava, eu tava de boa. Eles só olhava pra mim "Nó, véi, cê é a única pessoa que eu vejo que vende droga e num fica com flagrante.". "Eu num vendo droga não.” Eu mentia na cara deles: "Num vendo droga não, moço." "Não? Cê fica o dia inteiro fazendo o quê?" "Eu fico o dia inteiro mexendo no celular, mexendo no wi-fi na rua. Só a internet cortando aqui, ó.” (Ingrid)

Ingrid permaneceu em Belo Horizonte entre junho de 2017 e abril de 2018. Visitava sua família quinzenalmente em sua cidade natal, mas retornava sem problemas. Nunca evadiu da semiliberdade. Em uma dessas visitas, 
reencontrou Fernando, que já havia sido solto, e iniciaram relacionamento. Contou que o namorado continuava sendo patrão do tráfico, mas que ela não estava mais envolvida, mantendo apenas o uso de maconha. Na Casa feminina, era uma líder, capaz de promover paz e guerra entre as adolescentes, mas, assim como na trajetória infracional, exercia essa função de forma velada.

Em sua narrativa, demonstrou ter iniciado um movimento de reflexão sobre o ato infracional praticado. Tinha receio de andar pelas ruas de sua cidade nos finais de semana em que fazia a visita à família, pois era vista como "assassina do namorado". Temia sofrer alguma represália. Contou que os atendimentos com o psicólogo e a advogada da Casa feminina foram muito importantes para ela e que, num dado momento, pensou em procurar a família de Robson e conversar sobre o ocorrido, numa tentativa de esclarecer que não tinha intenção de matá-lo:

Eu ia chamar praticamente a família do cara pra conversar com eles, pra tentar explicar pra eles o quê que aconteceu. Só que... conversei com meu namorado [Fernando]. Ele falou: "Oh, Ingrid, cê acha que eles vão entender o quê que cê vai falar? Querendo ou não, cê tirou a vida do filho da mulher. Cê acha que ela vai te perdoar ocê falando que foi sem querer? Nunca que ela vai te perdoar.” Aí... eu fiquei meio assim... Aí ele "Então num tem porque cê ficar se escondendo dos outro. Porque infelizmente cê tem que viver sua vida daqui pra frente e esquecer atrás. Num é fácil... cê dormiu e no outro dia cê esqueceu tudo, mas tem que ir indo". Aí eu to indo nessa aí, igual meu namorado falou. (Ingrid)

Mas cê tinha pensado em ter essa conversa com a família...

Pensei. Mas só que eu desisti, que esse povo é muito doido. Pensei quando eu tava cumprindo aqui. Pensei no que eu ia falar. Falei pro psicólogo. Chamei o psicólogo pra ter atendimento, né, pra mim perguntar. Perguntei ele. Aí ele falou assim: "Cê acha que cê falando isso vai resolver?”. Aí eu pensava que sim, que ia resolver. Só que... aí eu fui vendo, vendo, vendo a situação e falei "Num vai resolver de nada." A minha verdade.... o que vai resolver é eu tomar coragem e enfrentar tudo de frente. Não tem como eu esconder mais. Aconteceu, filho. Posso até enfiar debaixo da terra e voltar que num... aconteceu do mesmo jeito. Então... aí eu fui falei, eu vou enfrentar de frente. Aí os outro vem e me pergunta eu sobre esses trem... Fala que... tipo... "Ah, que todo 
mundo fica falando que o cara te batia." Eu falei "Ah, no meu processo tá lá ó, que eu provei lá... é... meu corpo de delito. Eu tava agredida pra cacete, eu apanhei demais. Só que num é o motivo deu ter feito isso. Eu falei "Num é só porque eu apanhei que eu tive a intenção de matar". (Ingrid)

Aos 17 anos, foi desligada da Casa de semiliberdade e voltou a morar em sua cidade com a mãe e irmãos, não sendo apreendida posteriormente, ao menos até completar 18 anos de idade.

Essa breve construção do curso de vida de Anderson e Ingrid não contempla todas as experiências significativas apresentadas por eles durante as entrevistas, mas nos permitem verificar, como destacou Benson (2013), que as trajetórias no crime não ocorrem isoladas de outras trajetórias. O percurso na família de origem, na educação, no mundo do trabalho entre outros se cruza ao longo da vida e da construção do sujeito. O ingresso no mundo do crime se dá em um processo.

Dois adolescentes que nasceram e cresceram em comunidades pobres, assistindo à dinâmica do tráfico de drogas da porta de casa, antes mesmo de aderirem ao movimento, já conheciam pessoas envolvidas com o tráfico e, ainda que de longe, sabiam os passos para o ingresso. Anderson foi convidado a vender drogas, pois já conhecia os outros meninos envolvidos e estava sempre por ali, próximo dos locais de venda de drogas, já havia guardado dinheiro e feito algumas entregas. Ingrid procurou o chefe do tráfico e se ofereceu para ocupar uma vaga naquela firma. Aprendem olhando e convivendo com os amigos. Assumem responsabilidades, têm horário para chegar e sair, relação de subordinação, um plantão para cumprir. Ambos têm familiares com histórico de envolvimento no tráfico. Em determinado momento, fica incompatível continuar estudando e estar no movimento. Optam pelo tráfico. Anderson consegue desempenhar trabalhos lícitos ao longo dos anos em que também estava no movimento. Sinalizam satisfação, alegria, forte emoção e adrenalina ao relatarem seu envolvimento, episódios de fuga da polícia, poder de aquisição de bens e possibilidades de lazer e diversão. Mas ambos decidem deixar a trajetória infracional enquanto estão cumprindo a medida de semiliberdade. Fizeram cursos, voltaram a estudar, se reaproximaram das respectivas famílias.

Anderson e Ingrid não tiveram episódios de evasão. Contaram a respeito do processo de reflexão sobre a trajetória infracional que iniciaram a partir 
dos atendimentos técnicos e das atividades na semiliberdade. Começaram a fazer planos para o futuro: ser mecânico e ser cabeleireira, formar a própria família. Até o momento em que consegui ter notícias deles, mesmo após o desligamento, soube que Ingrid continuou o namoro com Fernando, na esperança de que ele deixasse o crime, mas sabendo que, devido à guerra do tráfico em sua cidade, seria difícil que isso acontecesse, pois era uma forma de ele estar protegido, com armas e "soldados", segundo ela. Anderson buscou meios de se afastar de sua guerra. Mudou-se de cidade para adiar o destino certo, mas fez novos desafetos. Voltou para Belo Horizonte, não para sua quebrada de origem, pois era perigoso. Ainda assim, foi encontrado por rivais e morto a tiros. Mais um jovem de periferia, vítima de um homicídio sem solução.

Os dois jovens percorreram etapas de busca por independência e realização pessoal. Quando entram de cabeça no tráfico, já estão passando mais tempo na rua que em casa, distantes da supervisão de adultos cuidadores e logo proclamam sua autonomia em relação à família. Ainda que a questão material permeie todo o percurso, pois Anderson e Ingrid também buscavam oportunidades de prosperidade financeira quando aderiram ao tráfico, as narrativas também mencionam valores imateriais e simbólicos importantes como respeito, autonomia, poder, valorização do lugar do chefe/patrão, lealdade ao grupo.

Um ponto importante a ser destacado nas entrevistas é a escolha do início da narrativa, pois o evento selecionado pelo entrevistado para iniciar sua fala está intimamente vinculado à sua atual situação biográfica (ROSENTHAL, 2014; SANTOS, 2012). Esse ponto fica claro nas narrativas apresentadas: a primeira situação narrada pelos dois adolescentes referia-se a um momento de virada biográfica, ou seja, experiências que desencadearam uma série de mudanças na vida dos narradores (SANTOS, 2012), culminando em sua condição presente de socioeducando em uma unidade de semiliberdade. A virada biográfica é, pois, o evento com que o narrador estabelece um vínculo entre o passado e o presente, utilizando o seu estoque de experiências passadas para interpretar sua situação atual. Como destaca Rosenthal, a partir da virada biográfica, o narrador reinterpreta seu passado e passa a projetar seu futuro de uma nova maneira (ROSENTHAL, 2014, p.237).

Ingrid inicia contando que fazia várias atividades, estudava, fazia aulas de dança e esportes, tinha amigos e quase não ficava em casa, tomada por essas ocupações. Porém, após iniciar namoro com Robson, devido aos ciúmes 
deste, teve que abandonar tudo e viver dedicada ao namorado. Ela continua narrando como era esse relacionamento, as violências sofridas, a decisão de terminar o namoro e a não aceitação de Robson, o que culminou com o assassinato dele durante uma briga do casal. Sua última frase na narrativa inicial foi "Aí eu tô aqui.", buscando indicar um caminho lógico, para ela, entre o início desse relacionamento e o ato infracional. Antes de iniciar a entrevista, apresentei a ela meu interesse em conhecer a trajetória de vida de adolescentes que estão cumprindo a semiliberdade. Em seu sistema de relevância e tipificações, Ingrid escolheu me contar como ela foi parar naquela instituição, acautelada pela prática de um homicídio. Poderia ter iniciado seu relato falando de seu nascimento, da família, da briga e rompimento dos vínculos com o pai. Ela decidiu saltar toda a sua trajetória anterior de envolvimento com o tráfico de drogas, que somente apareceu em um segundo momento da entrevista. Sua decisão foi de estabelecer uma conexão entre o seu passado e o seu presente: o que me trouxe aqui?

De modo semelhante, Anderson iniciou a narrativa contando que sua mãe havia sido presa. Voltou a um fato ocorrido quando tinha nove anos de idade. Também não escolheu iniciar falando de seu nascimento, tampouco do ato infracional (roubo) que deu origem ao cumprimento da medida de semiliberdade. Anderson estabeleceu uma conexão entre o início de sua trajetória infracional e o fato de sua mãe ter sido presa quando ele ainda era uma criança, quando ainda nem desconfiava do envolvimento dela e pouco sabia sobre o crime. Ele narra como foi se dando a descoberta acerca desse mundo e seu ingresso no tráfico de drogas: a mãe ausente, as visitas ao presídio, teve que passar pelos procedimentos de revista, a comida partida e virada num saco pelos agentes prisionais. Sem a supervisão da mãe, passava mais tempo na rua. Seu amigo de infância era primo do gerente do tráfico. Surge o convite e ele aceita. A última frase de sua narrativa inicial é: "E eu tô aí. Eu fui lá e rodei. Agora tô pagando medida, uê.” Assim como Ingrid, pareceu-me que buscava responder a uma pergunta que não lhe foi feita diretamente: o que te trouxe aqui?

No Brasil, desde a década de 1970, várias pesquisas em Ciências Sociais se dedicam ao tema da criminalidade juvenil. Um número considerável de elementos foi indicado como causa do envolvimento infracional de jovens, como a precariedade material, a falta de supervisão dos pais, revolta, frustração, machismo, etos guerreiro, hedonismo, falta de perspectivas de ingresso 
no mundo do trabalho (ZALUAR, 1985; 2007; 2014; CECHETTO; 2004). Nesse sentido, a exacerbação da masculinidade e do individualismo entre os jovens, na busca da satisfação imediata dos prazeres, explicaria em parte sua adesão ao tráfico de drogas. Ao compreender que se encontra em condições precárias de vida, ao não vislumbrar possibilidades de superação desse status por meio da inclusão no mercado de trabalho e, além disso, por sentir certo desprezo ou aversão pelo trabalho, já estando próximo das redes do tráfico de drogas em sua comunidade de origem, alguns adolescentes iniciariam, assim, sua trajetória infracional. Nesse movimento, os jovens passam a recusar o estilo de vida dos pais e, consequentemente, o estilo de vida e os valores da sociedade como um todo, na busca da realização pessoal. (LYRA, 2013, p.28).

Contudo, estudos como os de Feltran (2008; 2018), Malvasi (2012; 2013) e Lyra (2013), assim como o presente estudo, reconhecem os elementos imateriais e simbólicos da adesão do jovem ao crime, mas não sinalizam essa renúncia aos valores fundamentais da sociedade. Os jovens sujeitos de todas essas pesquisas também têm suas identidades forjadas sob os conceitos de honestidade, respeito aos familiares (mães e avós, principalmente), lealdade, "correr pelo certo", rejeição do "errado" (como o estupro, roubar do tráfico ou alcaguetar).

A trajetória infracional de Anderson correu paralela à trajetória escolar e à trajetória profissional por cerca de três anos. Apesar de cumprir um plantão no tráfico, continuou por bastante tempo frequentando as aulas e realizando trabalhos e bicos lícitos. Ingrid tinha uma rotina que sinalizava laços fortes com a escola, o grupo de dança e o time de futebol de salão dos quais fazia parte. Ao contrário do que se pode imaginar, não apenas jovens que vivem no ócio absoluto aderem às tramas do tráfico de drogas. Até os 13 anos, Ingrid tinha várias redes de apoio e de controle informal, mas algo muda aos 14 anos, como ela relatou.

No caso de Anderson, os laços familiares e o controle exercido por adultos cuidadores foram se tornando frouxos e frágeis ainda na infância, após a prisão da mãe,uma mãe envolvida com o tráfico de drogas, mas sem levantar a suspeita do filho. Anderson relata que passou a permanecer mais tempo na rua, sem a supervisão de adultos apenas após a prisão da mãe, que antes exercia autoridade sobre ele. $\mathrm{O}$ contato com a dinâmica de funcionamento de um presídio, o tráfico de drogas presente na vizinhança, a forte amizade com um adolescente cuja família era do movimento ofereceram oportunida- 
des a fim de que Anderson voltasse seu olhar para o "mundo do crime”, que passou a ser uma trajetória possível.

A partir do envolvimento, Anderson e Ingrid abandonam precocemente os estudos, a dança e o esporte, ambos considerados bons jogadores, o que limita suas possibilidades de acesso a determinados cargos no mercado de trabalho ou a um engajamento no esporte profissional. Separação dos pais, prisão da mãe, envolvimento de irmão no crime, interrupção das práticas esportivas, evasão escolar, apreensões pela polícia, processos judiciais, experiências de aprisionamento e de rotulação ("traficante”, "assassina do namorado”) integram o rol de desvantagens acumuladas por esses jovens, que podem dificultar uma possível saída do crime, caso queiram.

Desse modo, longe de se tratar de uma questão simples, o que move esses garotos e garotas, as interpretações que fazem sobre sua história para, em determinado momento da vida, optarem por aderir à prática infracional, não pode ser explicado como o início de um processo despertado por um desejo. Pelo contrário, como ensina Lyra (2013, p. 72), a adesão ao crime é parte de um processo social singular que teve início muito antes. É a culminação de uma trama social, como mostram as trajetórias de Anderson e Ingrid.

\section{Considerações finais}

A construção do curso de vida dos adolescentes a partir de seus relatos biográficos mostra como as trajetórias e também a vida dos sujeitos estão conectadas. A trajetória familiar, a trajetória escolar, a trajetória construída no território estão interligadas e, ao conhecer um pouco de cada uma delas, a partir das percepções dos próprios adolescentes, compreendemos como as ações dos sujeitos estão interligadas com o passado vivido e o presente que se coloca. O horizonte de oportunidades que está à frente do adolescente está absolutamente vinculado às suas trajetórias até então vivenciadas ao seu território e às relações ali estabelecidas desde a primeira infância, formando o sujeito. Além disso, o adolescente está conectado de maneira pessoal e profunda a outras vidas, outros corpos, como os pais, irmãos, avós, primos, amigos, namorados.

A pesquisa mostrou que todos os 18 adolescentes entrevistados, assim como Anderson e Ingrid, conviviam com familiares envolvidos na dinâmica criminal antes de aderirem a práticas infracionais. Essa conexão com outros 
indivíduos que transitam pelo "mundo do crime” não é definidora da adesão do adolescente, mas contribui para a formação desse horizonte de oportunidades em que o envolvimento no tráfico ou em roubos se apresenta como um dos percursos possíveis. A partir dos relatos biográficos dos adolescentes, no que se refere às suas famílias, sobressai a complexidade das relações, das configurações e modos de vida. Esses grupos familiares não podem ser classificados de forma simplista como "protetores" ou "negligentes", como "famílias envolvidas no crime" ou "não envolvidas no crime”. A mesma família que ora exerce papel de proteção também é formada por membros enlaçados na criminalidade.

Não há um determinismo que torna irresistível a adesão do adolescente ao "mundo do crime”, mas assim como há várias diferenças entre as trajetórias dos entrevistados, há também vários pontos de convergência e semelhança, como a maior participação de mulheres (mães, avós e tias) e escassa participação de homens (pais, padrastos, tios, avôs) na criação dos adolescentes. A maioria reside em territórios onde estão mais expostos ao convívio com a dinâmica infracional; vivenciam ao longo de suas trajetórias um processo de acúmulo de desvantagens que podem ser obstáculos às mudanças de percurso, caso o adolescente assim deseje. Dentre as desvantagens acumuladas, estão a baixa escolaridade e evasão escolar, exposição a situações de violência e à criminalidade no território de moradia, pais ocupando cargos de baixa remuneração e expostos à precarização do trabalho, fragilização de vínculos familiares, histórico de apreensões, rotulação por policiais, vizinhos e outros, as passagens por unidades socioeducativas e a incorporação de uma linguagem e hábitos do "mundo do crime".

Como já destacado por Luiz Eduardo Soares (2004), existem laços prováveis entre as seguintes realidades: pobreza, baixa escolaridade, menor acesso a oportunidades de trabalho, maior chance de sofrer o desemprego e o desamparo econômico e social, angústia e insegurança, violência doméstica, uso abusivo de álcool e outras drogas, ambiente propício ao absenteísmo, à desatenção e à rejeição dos filhos. Esses elementos impactam na construção da identidade e na absorção de valores da sociedade. Soares (2004) salienta que crianças e adolescentes com esse histórico tendem a apresentar maior propensão a experimentar deficiências de aprendizado e que dificuldades na família, na escola e a pressão para o ingresso precoce no mercado de trabalho acabam por precipitar o abandono escolar, o que reduz ainda mais as chances 
de acesso ao mercado de trabalho e amplia a probabilidade de reprodução do círculo da pobreza naquela geração (SOARES, 2004, p. 139-140).

Um ponto importante que se soma ao rol de desvantagens acumuladas ao longo do curso de vida é o ingresso do adolescente no Sistema de Justiça Juvenil. Quando o adolescente que praticou uma infração é apreendido pela polícia, é acionada uma engrenagem que pode alterar o status do adolescente frente a seus interlocutores, modificando as relações sociais com família, escola, vizinhança, a polícia, os juízes, os profissionais do Sistema Socioeducativo. O adolescente passa a "ter passagem" e cada nova apreensão vai se somando às anteriores, tornando o adolescente cada vez mais conhecido e rotulado, o que impacta em sua imagem pública e em sua autoimagem, como destaca Becker (2008).

A partir da análise dos relatos biográficos dos adolescentes, foi possível perceber que o engajamento e a permanência em uma trajetória infracional não ocorrem de forma inesperada, surpreendente, de uma hora para outra. Ao contrário, trata-se de um processo, um percurso que o adolescente está (ou estava) percorrendo, atravessado por elementos protetivos que poderiam ter dificultado sua adesão ao crime e elementos que o expuseram às dinâmicas infracionais. De um modo geral, os pontos de proteção parecem ter sido mais frágeis que os pontos de exposição às dinâmicas infracionais. Somados às decisões e ações individuais dos adolescentes e ao acúmulo de desvantagens ao longo do curso de vida, têm-se os elementos que podem nos ajudar a compreender o processo de adesão dos jovens à dinâmica infracional.

Como foi possível perceber a partir das entrevistas, não se trata de indivíduos que nasceram "bandidos desalmados". São bastante perceptíveis no curso de vida dos adolescentes os processos de aprendizagem vivenciados que contribuíram para que se tornassem infratores. Um aprendizado prático, transmitido dos mais velhos aos iniciantes, que engloba não apenas as formas de praticar infrações, mas também uma sociabilidade, um modo de ser e de viver, compartilhamento de valores, compreensão das implicações e perigos. Nesse processo, o adolescente aprende a atuar no tráfico de drogas, em roubos, a usar armas de fogo e aprende também a ter "maldade", uma expertise necessária à sobrevivência no crime.

Assim como o ingresso na criminalidade se dá de forma processual e as vivências em outras trajetórias são importantes para se compreender a adesão dos adolescentes a práticas infracionais, também o rompimento, quando 
ocorre, se dá gradualmente e, antes de uma fragilização ou ruptura dos vínculos com o "mundo do crime", o adolescente inicia um processo interior e subjetivo de desenlace. Assim como no ingresso, cada jovem que rompe com a criminalidade tem seu próprio ritmo de desistência. Nesse processo, várias questões podem se apresentar ao adolescente: como não depender dos recursos oriundos das práticas infracionais? Como lidar com os inimigos, desafetos e policiais que continuam em "guerra"? Como ressignificar a sensação de pertencimento, o reconhecimento, a visibilidade e outros aspectos simbólicos que contribuíram para a permanência do adolescente no movimento? Como construir outras formas de resolução de conflitos não violentas?

Não apenas para os adolescentes entrevistados, mas para qualquer indivíduo, não é algo simples prospectar o futuro aos 16 ou 17 anos de idade. Cada pessoa faz planos para si mesma a partir de seu estoque de vivências e conhecimentos, das suas experiências significativas, considerando passado e presente. As possibilidades, novos e antigos percursos estão abertos a esses adolescentes que, como sujeitos de ação, desenharão seu futuro. A nenhum dos sujeitos desta pesquisa, está pré-determinado que continuem envolvidos ou saiam do "mundo do crime". Mas nessa construção, porém, não é possível desconsiderar as desvantagens acumuladas ao longo de cada curso de vida.

Por fim, gostaríamos de destacar que esta pesquisa buscou compreender e apresentar adolescentes existindo, construindo suas identidades, suas interpretações sobre as vivências, a forma como compreendem seu passado, presente e futuro, elementos que, muitas vezes, escapam das estatísticas. Esses adolescentes têm muito a nos dizer e precisamos fazer o exercício de escutá-los, de tentar compreendê-los. Assim como eles têm dificuldades em projetar o futuro, também nós, sociedade, pesquisadores, técnicos e gestores das políticas públicas, estamos ainda tateando e ensaiando planos possíveis para esses adolescentes. Precisamos nos questionar quanto às estratégias que temos elaborado e às quais temos submetido esses jovens nas escolas, instituições de acolhimento, projetos pedagógicos e esportivos e também nas medidas socioeducativas. Estratégias que construímos tantas vezes à revelia de seus destinatários e que nos fazem questionar como ainda podemos acreditar que intervenções "fabricadas" sem a participação e o protagonismo desses jovens podem ter efetividade.

Talvez, por meio da escuta ativa, de novas oportunidades e experiências de troca, norteadas pela horizontalidade, pelo acolhimento e pelo respeito, seja 
possível construir novos percursos possíveis com esses adolescentes, para que tenham maior liberdade de avaliação e escolha acerca de seu futuro.

\section{Referências}

BECKER, Howard S. (2008) Outsiders: estudos de sociologia do desvio. Rio de Janeiro: Jorge Zahar Ed.

BENSON, Michael L. (2013) Crime and the lifecourse: an introduction. $2^{\text {nd }}$ ed. New York: Routledge.

BERGER, Peter L.; LUCKMANN, Thomas. (2014) A construção social da realidade: tratado de sociologia do conhecimento. 36 Ed. Petrópolis, Rio de Janeiro: Vozes.

BRASIL. Estatuto da criança e do adolescente (1990). Lei n ${ }^{\circ} 8.069$ de 13 de julho de 1990. Dispõe sobre o Estatuto da criança e do adolescente e dá outras providências.

BUGNON, Géraldine; DUPREZ, Dominique. (2010) Olhares cruzados sobre o atendimento institucional aos adolescentes infratores no Brasil. In: Dilemas: Revista de Estudos de Conflito e Controle Social, Vol. 3, $\mathrm{n}^{\mathrm{0}} 7$, Jan/Fev/Mar, p. 143-179.

CECHETTO, Fátima Regina. (2204) Violência e estilos de masculinidade. Rio de Janeiro: FGV.

FELTRAN, Gabriel de Santis. (2008) Fronteiras de tensão: um estudo sobre política e violência nas periferias de São Paulo. (Tese de Doutorado). Universidade Estadual de Campinas (UNICAMP). . Irmãos: uma história do PCC. (2008) $1^{\mathrm{a}}$ Ed. São Paulo:

Companhia das Letras.

LYRA, Diogo. (2013) A república dos meninos: juventude, tráfico e virtude. Rio de Janeiro: Mauad Editora Ltda e FAPERJ.

MALVASI, Paulo Artur. (2012) Interfaces da vida loka: um estudo sobre jovens, tráfico de drogas e violência em São Paulo. (Tese de Doutorado). Universidade de São Paulo (USP). - (2013) A "mente" e o homicídio: a gestão da violência no tráfico de drogas em São Paulo. Dilemas: Revista de Estudos de Conflito e Controle Social. Vol. 6, no 4, Out/Nov/Dez p. 675-698.

MINAS GERAIS. Centro Integrado de Atendimento ao Adolescente Autor de Ato Infracional. (2018) Relatório Estatístico 2017. Belo Horizonte: Vara Infracional da Infância e da Juventude do Tribunal de Justiça do Estado de Minas Gerais. 
MINAS GERAIS. Secretaria de Estado de Defesa Social. Subsecretaria de Atendimento às Medidas Socioeducativas. (2015) Regimento único das unidades de execução da medida socioeducativa de semiliberdade.

ROSENTHAL, Gabriele. (2014) História de vida vivenciada e história de vida narrada: a interrelação entre experiência, recordar e narrar. In: Civitas, Porto Alegre, v. 14, n. 2, maio-ago, p.227-249.

- (2017) História de vida vivenciada e história de vida narrada:

Gestalt e estrutura de autoapresentações biográficas. Porto Alegre: EDIPUCRS.

SANTOS, Hermílio. (2009) Adolescentes infratores e interpretações do mundo da vida: alteridade e relações de gênero. Comunicação apresentada no XIV Congresso Brasileiro de Sociologia. Rio de Janeiro.

. (2012) Ação e relevância em narrativas de adolescentes autoras de atos infracionais. Contemporânea v. 2, n. 2, p. 489-512.

SANTOS, Hermílio; OLIVEIRA, Patricia; SUSIN, Priscila. (2014) Narrativas e pesquisa biográfica na sociologia brasileira - revisão e perspectivas.

In: Civitas, Porto Alegre, v. 14, n. 2, maio-ago., p. 359-382.

SOARES, Luiz Eduardo. (2004) Juventude e violência no Brasil contemporâneo. In: NOVAES, Regina; VANNUCHI, Paulo (Orgs.). Juventude e sociedade: trabalho, educação, cultura e participação. São Paulo: Instituto Cidadania, Fundação Perseu Abramo, p.130-159

ZALUAR, Alba. (1985) A máquina e a revolta. São Paulo: Brasiliense.

. (2007) Democratização inacabada: fracasso da segurança pública. In: Estudos Avançados, São Paulo, v. 21, n. 61, p. 31-49.

. Etos guerreiro e criminalidade violenta. (2014) In: LIMA, Renato Ségio; RATTON, José Luiz; AZEVEDO, Rodrigo G. (Orgs.). Crime, Polícia e Justiça no Brasil. São Paulo: Contexto, p. 35-50.

\section{(cc) $\mathrm{BY}$}

Licenciado sob uma Licença Creative Commons Attribution 3.0 
